\title{
Carbon footprinting of potato (Solanum tuberosum L.) production systems in Zimbabwe
}

\author{
O. Svubure ${ }^{1,2, *}$, P.C. Struik ${ }^{2}$, A.J. Haverkort ${ }^{3,4}$, J.M. Steyn ${ }^{4}$ \\ ${ }^{I}$ Chinhoyi University of Technology, Department of Irrigation and Water Engineering, Chinhoyi, Zimbabwe \\ ${ }^{2}$ Centre for Crop Systems Analysis, Wageningen University and Research Centre, Wageningen, The Netherlands \\ ${ }^{3}$ Plant Research International, Wageningen University and Research Centre, Wageningen, The Netherlands \\ ${ }^{4}$ Department of Plant Production and Soil Science, University of Pretoria, Pretoria, South Africa
}

*Corresponding author: oniwardsvubure @ gmail.com

\begin{abstract}
Agriculture contributes significantly to the world greenhouse gas (GHG) emissions. Farmers need to fine-tune agricultural practices to balance the trade-off between increasing productivity in order to feed the growing global population and lowering GHG emissions to mitigate climate change and its impact on agriculture. We conducted a survey on the major cultural practices in four potato production systems identified in Zimbabwe, namely the large scale commercial, communal area, A1 and A2 resettlement production systems. The resettlement production systems were formed from the radical Fast Track Land Reform Programme initiated in 2000, which completely changed the landscape of commercial agriculture in Zimbabwe. We used the survey data as input into the 'Cool Farm ToolPotato' model. The model calculates the contributions of various production operations to the total GHG emission. Experienced growers were targeted. The average carbon footprint calculated was 251 $\mathrm{kg} \mathrm{CO}$ eq./t potato harvested, ranging from 216 to $286 \mathrm{~kg} \mathrm{CO}_{2}$ eq./t in the communal area and $\mathrm{A} 2$ resettlement production systems, respectively. The major drivers of the GHG emissions were fertiliser production and soil-related field emissions, which together accounted for on average $56 \%$ of the total emissions across all the production systems. Although mitigation options were not assessed, the model output displays the factors/farm operations and their respective emission estimates consequently allowing the grower to choose the inputs and operations to reduce the carbon footprint. Opportunities for benchmarking, as an incentive to improve emission performance, exist given the large variation in GHG emission among growers.
\end{abstract}

Key words: GHG emission, Irish potato, benchmarking, climate change mitigation, Cool Farm ToolPotato, Zimbabwe.

\section{Introduction}

Agriculture faces the great challenge of increasing food production to meet the demands of a growing population projected to reach $9-10$ billion by 2050 , while at the same time decreasing agriculture's global environmental footprint (Bellarby et al., 2014). In the developing countries, rates of input use, especially mineral fertilisers for major cereal crops, are generally low thereby limiting yield (Mueller et al., 2012). Opportunities therefore exist to increase crop yields in this region through increases of nutrient application rates. However, increasing synthetic fertiliser application rates on the 
underperforming farmlands will come at a cost by also increasing greenhouse gas (GHG) emissions (Bellarby et al., 2014). The agricultural sector is estimated to have contributed about 10-12\% to global anthropogenic GHG emissions in 2005, and about 50 and $60 \%$ of methane and nitrous oxide gas emissions, respectively (Smith et al., 2008). GHG emissions from agriculture are projected to increase further, with the highest emission growth rates anticipated in sub-Saharan Africa due to increased livestock populations and synthetic fertilisers use (Reay et al., 2012). There is a need to increase food production, but there is equally a need to minimise the negative environmental impact of GHG emissions. This strategy, approach or process whose precise definition is subject to considerable debate has been termed sustainable intensification or ecological intensification (Struik and Kuyper, 2014). Struik and Kuyper (2014) argue that intensification could be viewed as a transitional process from agricultural practices generally accepted as unsustainable to those regarded as environmentally sustainable. Applying this term in practice requires the quantification of the carbon footprint per unit of product or per unit cropped area while maintaining a record of input use, cultural practices and output to enable the assessment of production practices. The knowledge of the emission sources will assist in the determination of potential, 'climate smart' mitigation approaches. Moreover, such knowledge of the emission sources and their respective estimates will allow for benchmarking, where growers can compare their scores or performance against other growers at the local, regional, and national levels. Benchmarking uses the variation among growers on selected performance indicators as leverage or incentive to stimulate inter-farm competition and therefore continuously improve indicator performance (De Snoo, 2006).

In this study, the carbon footprint of the different Irish potato production systems in Zimbabwe was assessed. Irish potato production in Zimbabwe is generally capital intensive. It is normally grown under full or supplemental irrigation often using underground water sources, thereby incurring huge pumping energy and the associated carbon costs. The general synthetic fertiliser recommendations are 120,123 , and $149-199 \mathrm{~kg} / \mathrm{ha}$ of $\mathrm{N}, \mathrm{P}$, and $\mathrm{K}$, respectively, for an average yield of $30 \mathrm{t} / \mathrm{ha}$ fresh tuber yield (FAO, 2006; Manzira, 2011). This fertiliser recommendation is much higher than the rates used in other countries in the region. Irish potato has been selected as the pilot crop in this case study because of the cultural practices that involve extensive soil disturbances such as deep ploughing, disc harrowing to achieve a fine tilth seedbed, and two or three ridging operations. These practices tend to stimulate soil carbon losses through enhanced decomposition and erosion (Saggar et al., 2011). In addition, agricultural extension services recommend generous fertiliser applications which may not always be efficiently used by the crop (FAO, 2006). Another routine practice is frequent (sometimes weekly) fungicides and insecticides sprayings. Besides, since 2012, Irish potato is now regarded a national strategic food security crop similar to the staple maize (The Herald, 2012). Svubure et al. (2015) discusses the general cultural practices employed by potato growers in Zimbabwe. Four production systems for Irish potato can be identified in Zimbabwe (Svubure et al., 2015). These are 
the large scale commercial, communal area, A1 and A2-resettlement production systems. A detailed characterisation of these production systems and an estimate of the grower populations in each production system are outlined in Svubure et al. (2015).

Total GHG emissions in croplands come from several sources (Hillier et al., 2009; 2011). These include loss of carbon from extensive soil movement and turning during land preparation operations, fossil fuel use in the manufacture and use of synthetic fertilisers and biocides, tractor use and irrigation, and from the management of crop residues (Hillier et al., 2011). GHG emissions from African agriculture are primarily based on the International Panel on Climate Change (IPCC) emission factor approaches (Hickman et al., 2011). Such guidelines may not properly account for the sitespecific field level farmer management practices (Hickman et al., 2011; IPCC, 2006). The alternative approach is the use of statistical and process-based models which require model input data such as soil profile characterisation and weather data (Hickman et al., 2011). Such data is largely insufficient or unavailable in Zimbabwe and in most sub-Saharan African countries (Quiroz et al., 2014). Decision support tools that assess the impact of cultural practices on GHG emissions at the farm/field level, enabling the grower to decide on management practices lowering emissions have been recently developed (Hillier et al., 2011). This case study used an open source software tool, called the 'Cool Farm Tool' (CFT) (Hillier et al., 2011) to estimate the GHG emissions of the different Irish potato production systems in Zimbabwe and identify practices that contribute the most to the GHG emissions. The CFT integrates several globally-determined empirical models and uses them to calculate GHG emissions as $\mathrm{CO}_{2}$ equivalents (Hillier et al., 2011). GHG emission studies in Zimbabwe have been limited to measurements of fluxes of $\mathrm{N}_{2} \mathrm{O}, \mathrm{CO}_{2}$ and $\mathrm{CH}_{4}$ in experimental plots for cereal or cereal/legume rotations on regular croplands and in some agroforestry systems (e.g., Chikowo et al., 2004; Rees et al., 2006; Mapanda et al., 2011). So far, no studies on GHG emissions of potato production systems in Zimbabwe have been documented, providing no benchmark to assess future interventions to lower GHG emissions in potato production. The input data for the CFT-potato model are the inputs and cultural practices growers employ in crop production. Such information is usually readily available especially from experienced growers, hence there is tremendous opportunity to use the CFT-potato model and grower surveys at a wide scale to identify cultural practices, their GHG emission estimates and potential management approaches for mitigation. The CFT-potato model is very suitable to assess efficient use of energy in potato production as reflected in $\mathrm{CO}_{2}$ balances because a) all inputs and operations are dealt with; b) there is no need to measure actual energy use by farmers because the tool already has many conversions embedded; c) by bringing it down to a single figure estimate of $\mathrm{GHG}$ emission (e.g., $\mathrm{kg} \mathrm{CO}_{2}$ eq./t), it is immediately obvious which potato production system is most efficient. By looking at the factors most contributing to the GHG emission estimate, the tool allows rapid appraisal of each system. 
The first objective of this case study was to employ the approach of growers' survey data and use of the CFT-potato model to distinguish the four potato production systems that appeared after the land reform in terms of yields, inputs and efficient use of energy as reflected in $\mathrm{CO}_{2}$ balances. We expect the four systems to have very different resource use efficiencies and aim to quantify those differences using the CFT-potato model. The second objective was to identify practices which contribute the most to the GHG emission and derive from them generic means to make these systems more efficient. Finally the study also aimed to suggest possible mitigation measures to growers of the four distinct potato production systems.

\section{Materials and methods}

\section{Study area}

A growers' survey was conducted from 2011 to 2014. The Nyanga Eastern Highlands and the Highveld, the regions currently active in Irish potato production in Zimbabwe, were targeted for the survey. Covering nearly $117,000 \mathrm{~km}^{2}$, the extensive nature of the study area coupled with the unpaved road network made access to the growers' farms rather challenging.

\section{Sampling and data collection}

Data was collected on all the major cultural practices employed by the different grower categories in potato production in Zimbabwe. The cultural practices included land preparation, planting, fertiliser use, weed and pest management, water management, energy use and harvesting. Only growers with a minimum of five continuous years of potato growing experience were interviewed. This requirement made the data collected credible because such experienced growers had well-established routine practices such as land preparation, fertiliser application rates, and through harvesting practices. Their input levels and potato yields had generally stabilised. Generally all growers and/or their managers could readily respond to the questions asked on their practices in potato production. Soil samples were also collected mainly for texture, $\mathrm{pH}$, organic matter and NPK analyses. The department of Agritex in each area randomly picked the sample farmers from the pool of qualifying growers. Appointments were made in advance and the selected growers were visited for the data collection exercise.

In this study, three large scale commercial growers and four A2 resettlement growers were interviewed from the Quarantine area located in the Nyanga Eastern Highlands region. The Quarantine area is a demarcated area established by a statutory instrument in 1956 when the government started a potato breeding programme (Joyce, 1982). It is responsible for the initial three multiplications of foundation seed to produce grade AA1 through AA3 seed potato. Grade AA3 seed leaves the Quarantine area for further multiplications mainly in the Highveld to produce grade A1 through A3 seed potato, all of which are used for ware potato production. There are currently 27 growers, both large scale commercial and $\mathrm{A} 2$ resettlement in this area and only 21 are active (Ackerman, personal communication, 2012). Outside the Quarantine area, other growers interviewed within the Nyanga 
Table 1. Number of growers per production system interviewed in the Highveld and Eastern Nyanga Highlands regions of Zimbabwe, in the period 2011-2014.

\begin{tabular}{|c|c|c|c|c|c|}
\hline \multirow{2}{*}{$\begin{array}{l}\text { Agro-ecological } \\
\text { region }\end{array}$} & \multirow{2}{*}{ Sampling area } & \multicolumn{4}{|c|}{ Production system } \\
\hline & & $\begin{array}{l}\text { Large-scale } \\
\text { commercial }\end{array}$ & $\begin{array}{c}\text { A2 } \\
\text { resettlement }\end{array}$ & $\begin{array}{c}\text { A1 } \\
\text { resettlement }\end{array}$ & $\begin{array}{c}\text { Communal } \\
\text { area }\end{array}$ \\
\hline Nyanga Eastern & Nyanga & 3 & 4 & 0 & 0 \\
\hline \multirow[t]{2}{*}{ Highlands } & $\begin{array}{l}\text { Quarantine } \\
\text { area }\end{array}$ & & & & \\
\hline & $\begin{array}{l}\text { Nyanga } \\
\text { district* }\end{array}$ & 1 & 5 & 4 & 18 \\
\hline \multirow[t]{5}{*}{ Highveld } & Harare & 5 & 2 & 0 & 0 \\
\hline & Bindura & 2 & 5 & 0 & 0 \\
\hline & Chegutu & 2 & 2 & 0 & 0 \\
\hline & Chinhoyi & 1 & 2 & 0 & 0 \\
\hline & Karoi & 1 & 3 & 0 & 0 \\
\hline Total & & 15 & 23 & 4 & 18 \\
\hline
\end{tabular}

*Excluding the Quarantine area 
Eastern Highlands region were 18 communal area, 4 A1 resettlement, and one of the four remaining large scale commercial growers. In the Highveld, a total of 11 and 14 large scale commercial and A2 resettlement growers respectively were interviewed. The Highveld had no communal area and A1 resettlement growers with the minimum five years continuous potato growing experience. Table 1 gives a summary of the number of growers interviewed.

\section{Calculation of GHG emission estimates}

The CFT-potato model used in this study is the Cool Farm Tool Potato Version 2 derivative as described by Haverkort and Hillier (2011), with entries unrelated to potato production such as livestock and cereal-related operations first removed. This is a limitation as most communal area growers use animal draft power. The CFT-potato model was adapted to estimate emissions from the seed material through storage of the harvested potato product. An important feature of the CFT-potato model is that it has been piloted before on several different farming systems, countries and commodities (Hillier et al., 2009; Haverkort and Hillier, 2011; Hillier et al., 2011; Cool Farm Tool Institute, 2012; Bellarby et al., 2014).

Data analysis

Individual farm values of GHG emissions from different sources under the different production systems were subjected to analysis of variance (ANOVA) of an unbalanced design using GenStat regression (VSN International, 2011). The agro-ecological regions were treated as blocks. The individual farm GHG emission values from the different sources were due to the treatment (or management) effect of the different production systems. The mean GHG emission values due to the different production systems were separated using the least significance difference (LSD) test at 5\% where the F-test showed significant effects. Further analysis of the relationship between the fresh potato yield in the different production systems and their respective total GHG emissions and $\mathrm{N}$ application rates were done using the Spearman Rank Correlation tests and associated t statistics that do not assume normality (Gomez and Gomez, 1984).

\section{Results and discussion}

\section{Input data to the CFT-Potato model}

Tables 2 and 3 summarize the mean values and range of the growers' interview data used as input into the CFT-potato model. The growers were derived from the four Irish potato production systems in Zimbabwe. Each grower data set was run separately and the mean GHG emissions for each activity were computed for each production system. Land preparation, spraying and other field operations by large scale and A2-resettlement growers are carried out by tractor drawn implements consuming diesel whereas these operations are done by animal-drawn implements in the smallholder production systems. However, domesticated animals are not carbon neutral. Direct emissions from livestock include $\mathrm{CH}_{4}$ from enteric fermentation and manure, and $\mathrm{N}_{2} \mathrm{O}$ from excreted urine and manure. A 
Table 2. Crop management, and field energy use data (average, minimum and maximum values) in the four Irish potato production systems in Zimbabwe used as input for the CFT-Potato model.

\begin{tabular}{|c|c|c|c|c|c|c|c|c|}
\hline \multirow[t]{2}{*}{ Input } & \multicolumn{2}{|c|}{ Large scale commercial } & \multicolumn{2}{|c|}{ A2 resettlement } & \multicolumn{2}{|c|}{ A1 resettlement } & \multicolumn{2}{|c|}{ Communal area } \\
\hline & average & range & average & range & average & range & average & range \\
\hline \multicolumn{9}{|l|}{ Farm general information } \\
\hline Yield (total) (t/ha) & 28 & $12-45$ & 23 & $12-36$ & 8 & $7-13$ & 17 & $8-45$ \\
\hline Yield (marketed) ( t/ha) & 26 & $11-43$ & 21 & $10-34$ & 8 & $7-11$ & 16 & $7-43$ \\
\hline Seed rate $(\mathrm{t} / \mathrm{ha})$ & 2.3 & $2.0-2.5$ & 2.2 & $0.9-3.0$ & 1.0 & $0.6-1.5$ & 1.6 & $0.5-3.0$ \\
\hline Total potato area per planting (ha) & 13 & $1-45$ & 8 & $0.4-25$ & 0.4 & $0.1-0.8$ & 1.1 & $0.4-4.0$ \\
\hline \multicolumn{9}{|l|}{ Crop management } \\
\hline Soil texture & fine & fine-coarse & coarse & fine-coarse & coarse & coarse-coarse & medium & fine-coarse \\
\hline Soil organic matter (\%) & 2.6 & $0.2-8.2$ & 2.0 & $0.2-8.6$ & 1.7 & $0.5-4.2$ & 3.2 & $0.3-7.8$ \\
\hline $\mathrm{pH}$ & 5.3 & $4.3-7.1$ & 5.4 & $4.1-7.1$ & 4.6 & $4.1-4.9$ & 4.3 & $4.1-5.0$ \\
\hline $\mathrm{N}(\mathrm{kg} / \mathrm{ha})$ & 181 & $60-240$ & 197 & $91-360$ & 94 & $45-164$ & 143 & $80-244$ \\
\hline $\mathrm{P}_{2} \mathrm{O}_{5}(\mathrm{~kg} / \mathrm{ha})$ & 284 & $144-405$ & 270 & $150-627$ & 91 & $38-150$ & 185 & $75-315$ \\
\hline $\mathrm{K}_{2} \mathrm{O}(\mathrm{kg} / \mathrm{ha})$ & 301 & $100-480$ & 218 & $64-408$ & 90 & $44-120$ & 137 & $49-216$ \\
\hline Seed treatments (number of applications/ha) & 1 & $1-1$ & 1 & $1-1$ & 1 & $1-1$ & 1 & $1-1$ \\
\hline Soil treatment (nematicide, $\mathrm{kg} / \mathrm{ha}$ ) & 20 & $13-30$ & 22 & $13-26$ & 17 & $17-17$ & 20 & $17-25$ \\
\hline Biocides (number of applications/ha) & 25 & $10-33$ & 22 & $14-41$ & 11 & $9-14$ & 18 & $11-28$ \\
\hline \multicolumn{9}{|l|}{ Field energy use } \\
\hline Fuel type: (diesel/petrol) & diesel & diesel & diesel & diesel & 0 & 0 & 0 & 0 \\
\hline Ploughing: Mouldboard (number of operations/ha) & 1 & $1-1$ & 1 & $1-1$ & 0 & 0 & 0 & 0 \\
\hline \multicolumn{9}{|l|}{ Seedbed preparations (number of operations/ha): } \\
\hline Ridging & 2 & $2-2$ & 2 & $2-2$ & 0 & 0 & 0 & 0 \\
\hline Disc harrowing & 1 & $1-1$ & 1 & $1-1$ & 0 & 0 & 0 & 0 \\
\hline Roller harrowing & 1 & $1-1$ & 1 & $1-1$ & 0 & 0 & 0 & 0 \\
\hline Planting furrow opening & 1 & $1-1$ & 1 & $1-1$ & 0 & 0 & 0 & 0 \\
\hline \multirow[t]{2}{*}{ Fertiliser spreading } & 1 & $1-1$ & 1 & $1-1$ & 0 & 0 & 0 & 0 \\
\hline & & & & & 0 & 0 & 0 & 0 \\
\hline \multicolumn{9}{|l|}{ Harvesting: } \\
\hline Potato windrower (number of operations) & 1 & $1-1$ & 1 & $1-1$ & 0 & 0 & 0 & 0 \\
\hline
\end{tabular}


Table 3. Irrigation, on-farm, and off-site transportation data (average, minimum and maximum values) in the four Irish potato production systems in Zimbabwe used as input for the CFT-Potato model.

\begin{tabular}{|c|c|c|c|c|c|c|c|c|}
\hline \multirow[t]{2}{*}{ Input } & \multicolumn{2}{|c|}{ Large scale commercial } & \multicolumn{2}{|c|}{ A2 resettlement } & \multicolumn{2}{|c|}{ A1 resettlement } & \multicolumn{2}{|c|}{ Communal area } \\
\hline & average & range & average & range & average & range & average & range \\
\hline \multicolumn{9}{|l|}{ Irrigation: } \\
\hline Percentage of area irrigated & 100 & $100-100$ & 100 & $100-100$ & 0 & 0 & 0 & 0 \\
\hline Irrigation system type & rain gun & rain gun - pivot & rain gun & rain gun - pivot & 0 & 0 & 0 & 0 \\
\hline Pumping depth (m) & 43 & $10-70$ & 30 & $10-70$ & 0 & 0 & 0 & 0 \\
\hline Horizontal water transport distance (m) & 615 & $200-1125$ & 361 & $100-850$ & 0 & 0 & 0 & 0 \\
\hline Total irrigation water applied to the area (mm) & 550 & $350-720$ & 465 & $300-850$ & 0 & 0 & 0 & 0 \\
\hline Grid electricity use (yes/no) & yes & yes & yes & yes & 0 & 0 & 0 & 0 \\
\hline Diesel use (yes/no) & no & no & no & no & 0 & 0 & 0 & 0 \\
\hline \multicolumn{9}{|l|}{ On-farm transportation per ha } \\
\hline Average distance: farm house/sheds to fields (km) & 6 & $5-8$ & 5 & $2-10$ & 0 & 0 & 0 & 0 \\
\hline Seed transport $(\mathrm{t})$ & 2.3 & $2.0-2.5$ & 2.2 & $0.9-3.0$ & 0 & 0 & 0 & 0 \\
\hline Fertiliser transport $(\mathrm{t})$ & 1.6 & $1.0-2.2$ & 1.7 & $0.9-3.0$ & 0 & 0 & 0 & 0 \\
\hline Harvested potato transport $(\mathrm{t})$ & 27 & $12-45$ & 22 & $12-36$ & 0 & 0 & 0 & 0 \\
\hline Monitoring and supervision $(\mathrm{km})$ & 399 & $315-504$ & 307 & $126-630$ & 0 & 0 & 0 & 0 \\
\hline \multicolumn{9}{|l|}{ Off-site transportation } \\
\hline Road transportation (seed, fertiliser, produce) $(\mathrm{t})$ & 40 & $36-44$ & 26 & $23-34$ & 2 & $1-2$ & 3 & $2-3$ \\
\hline
\end{tabular}


recent study in neighbouring Swaziland estimated GHG emissions from livestock at a total of $850 \mathrm{Gg}$ $\mathrm{CO}_{2}$ eq. per annum in 2010 from a livestock population of 0.5 million goats, 0.6 million cattle, 1.75 million poultry, 35000 pigs, 16000 sheep, and 13000 equines (Dlamini and Dube, 2014). While animals are important for the smallholder cropping systems for draft power provisions and other uses, the CFT-potato model does not consider entries not directly related to potato production such as livestock as already alluded to. Including the relatively large contributions of livestock into the computations of GHG emissions in smallholder potato production will potentially confound the estimates. Consequently, the CFT-potato model is adapted to estimate only emissions from the seed material through storage of the harvested potato product.

\section{GHG emissions per tonne of Irish potato}

Table 4 shows the different factors (or sources) of GHG emission in potato production in Zimbabwe. The mean GHG emission (in $\mathrm{kg} \mathrm{CO}_{2}$ eq./t fresh potato) from all the different sources were not significantly different ( $\mathrm{p}>0.05$ ) across the different production systems (Table 4). The average estimated carbon footprint for the four potato production systems was $251 \mathrm{~kg} \mathrm{CO}_{2}$ eq./t potato (Table 4). The least carbon footprint was $216 \mathrm{~kg} \mathrm{CO}_{2}$ eq./t potato for the communal area production system, while the A2 resettlement system had the highest of $286 \mathrm{~kg} \mathrm{CO}_{2}$ eq./t potato (Table 4). Recent studies on the Chilean potato cropping systems reported carbon footprints in the range $50 \mathrm{~kg} \mathrm{CO}_{2}$ eq./t potato for a low-input subsistence cropping system at Putre to over $200 \mathrm{~kg} \mathrm{CO}_{2}$ eq./t potato for a high-input La Serena late crop (Haverkort et al., 2014). The high level carbon footprint was mainly due to electricity used for pumping irrigation water and high $\mathrm{N}$ fertilisation (Haverkort et al., 2014). The study further concluded that the estimated mean carbon footprint across all potato production systems in Chile was $122 \mathrm{~kg} \mathrm{CO}_{2}$ eq./t potato, with $35 \%$ contribution from fertiliser production, $25 \%$ fertilizerinduced, and 15\% from seed production (Haverkort et al., 2014). These are generally lower than those from the Zimbabwean potato production systems. On the basis of similar studies in the Netherlands, Haverkort and Hillier (2011) reported even lower $\mathrm{CO}_{2}$ emissions ranging from 77 to $116 \mathrm{~kg} \mathrm{CO}_{2}$ eq./t potato. While the potato production systems and environments cited here are different from those in Zimbabwe, these relatively low $\mathrm{CO}_{2}$ emissions suggest that there is scope to lower the emissions in the Zimbabwean case.

The major driver of the total $\mathrm{CO}_{2}$ emissions in potato production in Zimbabwe is fertiliser production emissions which accounted for an average of $38 \%$ of the total emissions across all the production systems (Table 4). Combining fertiliser production with fertiliser-induced emissions, fertilisation accounted for $45-65 \%$ of the total $\mathrm{CO}_{2}$ equivalent emissions across the four potato production systems (Table 4). For example, while the general $\mathrm{N}$ fertiliser recommendation by agricultural extension service is $120 \mathrm{~kg} \mathrm{~N} / \mathrm{ha}$ (FAO, 2006), more than $70 \%$ of the growers interviewed in the study exceed this rate. On average, their $\mathrm{N}$ application rate is $158 \mathrm{~kg} \mathrm{~N} / \mathrm{ha}$ and the range is $45-360 \mathrm{~kg} \mathrm{~N} / \mathrm{ha}$ (Table 2). 
Table 4. Mean values of $\mathrm{CO}_{2}$ costs of producing Irish potato (in $\mathrm{kg} \mathrm{CO}_{2}$ eq./t potato) in the different potato production systems of Zimbabwe, $2011-2014$.

\begin{tabular}{|c|c|c|c|c|c|c|c|c|}
\hline \multirow[t]{2}{*}{ Production system } & \multicolumn{8}{|c|}{ Factors/sources } \\
\hline & $\begin{array}{c}\text { Seed } \\
\text { production }\end{array}$ & $\begin{array}{l}\text { Fertiliser } \\
\text { production }\end{array}$ & Soil-related & Pesticides & $\begin{array}{c}\text { Energy use } \\
\text { (excl. irrigation) }\end{array}$ & Irrigation & $\begin{array}{l}\text { Off-site } \\
\text { transport }\end{array}$ & Total \\
\hline Large-scale commercial & 33 & 83 & 39 & 26 & 8 & 73 & 0.4 & 263 \\
\hline A2-resettlement & 42 & 103 & 49 & 31 & 9 & 51 & 0.5 & 286 \\
\hline A1-resettlement & 38 & 91 & 70 & 41 & na & na & 0.5 & 240 \\
\hline Communal area & 31 & 100 & 48 & 36 & na & na & 0.5 & 216 \\
\hline LSD & $14^{\text {ns }}$ & $24^{\text {ns }}$ & $13^{\text {ns }}$ & $7^{\mathrm{ns}}$ & $1.3^{\mathrm{ns}}$ & $12^{\text {ns }}$ & $0.12^{\mathrm{ns}}$ & $56^{\mathrm{ns}}$ \\
\hline CV (\%) & 60 & 39 & 44 & 34 & 36 & 49 & 40 & 34 \\
\hline
\end{tabular}

Key: eq. = equivalent, excl. = excluding, na = not applicable, ns denotes non-significance at $\mathrm{p}<0.05$. 
Table 5. Spearman rank-order correlation analysis of nitrogen $(\mathrm{N})$ application rate and the corresponding greenhouse gas (GHG) emissions produced in the different production systems in Zimbabwe, 2011-2014.

\begin{tabular}{|c|c|c|c|c|c|c|c|c|c|c|c|c|}
\hline & \multicolumn{12}{|c|}{ Production system } \\
\hline & \multicolumn{3}{|c|}{ Large-scale commercial } & \multicolumn{3}{|c|}{ A2 resettlement } & \multicolumn{3}{|c|}{ A1 resettlement } & \multicolumn{3}{|c|}{ Communal area } \\
\hline & \multirow{2}{*}{$\begin{array}{c}\text { Mean N } \\
\text { use rate } \\
\text { (kg N/ha) }\end{array}$} & \multicolumn{2}{|c|}{$\begin{array}{c}\text { Mean GHG emission } \\
\text { (in } \mathrm{kg} \mathrm{CO}_{2} \text { eq.) }\end{array}$} & \multirow{2}{*}{$\begin{array}{c}\text { Mean N } \\
\text { use rate } \\
(\mathrm{kg} \mathrm{N} / \mathrm{ha})\end{array}$} & \multicolumn{2}{|c|}{$\begin{array}{c}\text { Mean GHG emission } \\
\text { (in } \mathrm{kg} \mathrm{CO}_{2} \text { eq.) }\end{array}$} & \multirow{2}{*}{$\begin{array}{c}\text { Mean N } \\
\text { use rate } \\
\text { (kg N/ha) }\end{array}$} & \multicolumn{2}{|c|}{$\begin{array}{c}\text { Mean GHG emission } \\
\text { (in } \mathrm{kg} \mathrm{CO}_{2} \text { eq.) }\end{array}$} & \multirow{2}{*}{$\begin{array}{c}\text { Mean N } \\
\text { use rate } \\
(\mathrm{kg} \mathrm{N} / \mathrm{ha})\end{array}$} & \multicolumn{2}{|c|}{$\begin{array}{c}\text { Mean GHG emission } \\
\text { (in } \mathrm{kg} \mathrm{CO}_{2} \text { eq.) }\end{array}$} \\
\hline & & per $\mathrm{t}$ & per ha & & per $\mathrm{t}$ & per ha & & per $\mathrm{t}$ & per ha & & per $\mathrm{t}$ & per ha \\
\hline & 181 & 263 & 6211 & 197 & 286 & 5337 & 94 & 240 & 1946 & 143 & 216 & 2868 \\
\hline \multicolumn{13}{|c|}{ Test statistics } \\
\hline $\mathrm{n}$ & \multicolumn{3}{|c|}{15} & & \multicolumn{2}{|c|}{23} & \multicolumn{3}{|c|}{4} & & \multicolumn{2}{|c|}{18} \\
\hline $\mathrm{r}_{\mathrm{s}}$ & & 0.28 & 0.54 & & 0.42 & 0.76 & & 0.92 & 0.80 & & 0.27 & 0.84 \\
\hline t-stat. & & 1.07 & 2.33 & & 2.11 & 5.30 & & 3.37 & 2.29 & & 1.12 & 6.12 \\
\hline t-crit. & & 2.16 & 2.16 & & 2.08 & 2.08 & & 3.30 & 2.18 & & 2.12 & 2.12 \\
\hline $\mathrm{p}$ & & $0.31^{\mathrm{ns}}$ & $0.04 *$ & & $0.04 *$ & $0.000 * *$ & & $0.04 *$ & $0.02 *$ & & $0.28^{\mathrm{ns}}$ & $0.000 * *$ \\
\hline
\end{tabular}

Key: eq. = equivalent, $*$ correlation is significant at the 0.05 level $(2$-tailed $), * *$ correlation is significant at the 0.001 level $(2$-tailed $)$, ns $=$ correlation is not significant at the 0.05 level (2-tailed). 
A Spearman's rank-order correlation test was carried out to determine the relationship between total Nfertiliser applied and the corresponding $\mathrm{GHG}$ emissions (in $\mathrm{kg} \mathrm{CO}_{2}$ eq./t potato) in the different potato production systems in Zimbabwe. Weak, positive correlations were observed in the large-scale commercial $\left(\mathrm{r}_{\mathrm{s}}=0.28, \mathrm{p}>0.05\right)$, A2 resettlement $\left(\mathrm{r}_{\mathrm{s}}=0.42, \mathrm{p}<0.05\right)$, and in the communal area $\left(\mathrm{r}_{\mathrm{s}}=\right.$ $0.27, \mathrm{p}>0.05$ ) production systems (Table 5). This implies that further increases in $\mathrm{N}$-fertiliser use in these high-input production systems result in only marginal increases in GHG emission per t potato. In the A1 resettlement production system, a strong, positive correlation $\left(r_{s}=0.92, p<0.05\right)$ was observed between $\mathrm{N}$-fertiliser use and the corresponding GHG emission per t potato produced (Table 5). The A1 resettlement is a low-input use system (Table 2), and increases in $\mathrm{N}$-fertiliser application rate will result in substantial GHG emissions per t potato produced.

Fertilisation emission depends on the fertiliser type, application rate and the soil characteristics (Hillier et al., 2011). In the communal area production system, fertilisation emission accounts for more than $60 \%$ of the total emissions per tonne fresh potato produced (Table 4). This is mainly due to the high fertiliser application rates applied, coupled by non-emitting operations such as gravity-fed irrigation and the use of animal-drawn equipment which was not assigned a generic animal emission value in the study. While in the large-scale and A2 resettlement systems, besides high fertiliser application rates, there is substantial irrigation and tractor energy costs (Table 4). In fact irrigation accounted for 28 and $18 \%$ of the total $\mathrm{CO}_{2}$ emission equivalents in the large-scale commercial and $\mathrm{A} 2$ resettlement production systems, respectively (Table 4).

Predictably, strong, negative correlations between fresh potato yield and the total $\mathrm{CO}_{2}$ emissions per tonne fresh potato were found in the large-scale commercial $\left(r_{s}=-0.56, p<0.05\right)$, A2 resettlement $\left(r_{s}\right.$ $=-0.57, p<0.05)$, and in the communal area $\left(r_{s}=-0.78, p<0.001\right)$ production systems (Table 6$)$. This indicates that increasing potato yields in these systems causes significant reductions in total GHG emissions per tonne fresh potato produced in these systems. Hence there is tremendous potential to reduce total emissions through improving the yields in the high-input use potato production systems. However, in the A1 resettlement production system, a strong, positive correlation $\left(\mathrm{r}_{\mathrm{s}}=0.76, \mathrm{p}<0.05\right)$ was observed between fresh potato yield and the corresponding total $\mathrm{CO}_{2}$ emissions per tonne fresh potato produced (Table 6). The A1 resettlement is a low-input production system and a yield gain from an increase in input use, such as $\mathrm{N}$-fertiliser application, will lead to substantial increase in total $\mathrm{CO}_{2}$ emissions per tonne fresh potato produced probably until the threshold of high-input use level is reached.

\section{GHG emissions per hectare}

The total GHG emissions ranged from $1,946 \mathrm{~kg} \mathrm{CO}_{2}$ eq./ha in the $\mathrm{A} 1$ resettlement to $6,211 \mathrm{~kg} \mathrm{CO}_{2}$ eq./ha in the large-scale production systems (Table 5 and 6). The soil-related GHG emissions from the smallholder potato systems were comparable to measurements reported by Mapanda et al. (2011) as 
Table 6. Spearman rank-order correlation analysis of the fresh Irish potato yields and the corresponding greenhouse gas (GHG) emissions produced in the different production systems in Zimbabwe, 2011-2014.

\begin{tabular}{|c|c|c|c|c|c|c|c|c|c|c|c|c|}
\hline & \multicolumn{12}{|c|}{ Production system } \\
\hline & \multicolumn{3}{|c|}{ Large-scale commercial } & \multicolumn{3}{|c|}{ A2 resettlement } & \multicolumn{3}{|c|}{ A1 resettlement } & \multicolumn{3}{|c|}{ Communal area } \\
\hline & \multirow[t]{2}{*}{$\begin{array}{l}\text { Mean } \\
\text { yield } \\
\text { (t/ha) }\end{array}$} & \multicolumn{2}{|c|}{$\begin{array}{c}\text { Mean GHG } \\
\text { emission } \\
\text { (in } \mathrm{kg} \mathrm{CO}_{2} \text { eq.) }\end{array}$} & \multirow[t]{2}{*}{$\begin{array}{l}\text { Mean } \\
\text { yield } \\
\text { (t/ha) }\end{array}$} & \multicolumn{2}{|c|}{$\begin{array}{c}\text { Mean GHG } \\
\text { emission } \\
\text { (in } \mathrm{kg} \mathrm{CO}_{2} \text { eq.) }\end{array}$} & \multirow[t]{2}{*}{$\begin{array}{l}\text { Mean } \\
\text { yield } \\
\text { (t/ha) }\end{array}$} & \multicolumn{2}{|c|}{$\begin{array}{c}\text { Mean GHG } \\
\text { emission } \\
\text { (in } \mathrm{kg} \mathrm{CO}_{2} \text { eq.) }\end{array}$} & \multirow[t]{2}{*}{$\begin{array}{l}\text { Mean } \\
\text { yield } \\
(\mathrm{t} / \mathrm{ha})\end{array}$} & \multicolumn{2}{|c|}{$\begin{array}{c}\text { Mean GHG } \\
\text { emission } \\
\text { (in } \mathrm{kg} \mathrm{CO}_{2} \text { eq.) }\end{array}$} \\
\hline & & per $\mathrm{t}$ & per ha & & per $\mathrm{t}$ & per ha & & per t & per ha & & per t & per ha \\
\hline & 28 & 263 & 6211 & 23 & 286 & 5337 & 8 & 240 & 1946 & 17 & 216 & 2868 \\
\hline \multicolumn{13}{|c|}{ Test statistics } \\
\hline$n$ & \multicolumn{3}{|c|}{15} & & \multicolumn{2}{|c|}{23} & \multicolumn{3}{|c|}{4} & & \multicolumn{2}{|c|}{18} \\
\hline$r_{\mathrm{s}}$ & & -0.56 & 0.19 & & -0.57 & 0.17 & & 0.76 & 0.95 & & -0.78 & 0.16 \\
\hline t-stat. & & -2.43 & 2.69 & & -3.16 & 0.81 & & 4.66 & 5.30 & & -4.96 & 0.66 \\
\hline t-crit. & & 2.16 & 2.16 & & 2.08 & 2.08 & & 4.30 & 3.18 & & 2.12 & 2.12 \\
\hline $\mathrm{p}$ & & $0.03 *$ & $0.04 *$ & & $0.005^{*}$ & $0.43^{\mathrm{ns}}$ & & $0.02^{*}$ & $0.01 *$ & & $0.0001 * *$ & $0.52^{\mathrm{ns}}$ \\
\hline
\end{tabular}

Key: eq. = equivalent, $*$ correlation is significant at the 0.05 level (2-tailed), ** correlation is significant at the 0.001 level (2-tailed), $\mathrm{ns}=$ correlation is not significant at the 0.05 level (2-tailed). 
fluxes of $\mathrm{N}_{2} \mathrm{O}, \mathrm{CO}_{2}$ and $\mathrm{CH}_{4}$ from soil grown to maize (Zea mays $\mathrm{L}$.) under different nitrogen $(\mathrm{N})$ fertiliser treatments in Zimbabwe. Using the static chamber methodology involving gas chromatography, Mapanda et al. (2011) estimated emissions of 0.1 to $0.5 \mathrm{~kg} \mathrm{~N} 2 \mathrm{O}-\mathrm{N} / \mathrm{ha}$ (29.8 to $149 \mathrm{~kg}$ $\mathrm{CO}_{2}$ eq./ha), 711 to $1,574 \mathrm{~kg} \mathrm{CO}_{2}-\mathrm{C} / \mathrm{ha}$ and -2.6 to $5.8 \mathrm{~kg} \mathrm{CH}_{4}-\mathrm{C} / \mathrm{ha}$ ( -65 to $145 \mathrm{~kg} \mathrm{CO}_{2}$ eq./ha). Also in the Siaya district in Kenya, total GHG emissions of 2,600 $\mathrm{kg} \mathrm{CO}_{2}$ eq./ha were reported from maize production of $1.7 \mathrm{t} / \mathrm{ha}$ (Palm et al., 2010). Case studies in Europe reported even much lower GHG emissions. For example, in east Scotland, mean carbon footprints across conventional, integrated and organic farm types ranged from $125 \mathrm{~kg} \mathrm{CO}_{2}$ eq./ha/yr for leguminous crops to $540 \mathrm{~kg} \mathrm{CO}$ eq./ha/yr for Irish potato (Hillier et al., 2009).

\section{GHG mitigation opportunities}

Achieving higher yields across all production systems could be the main driver to reduce the GHG emission on a per-tonne-produce basis. Meanwhile, the mean actual potato yield across the potato production systems in Zimbabwe is low. It ranges from $8 \mathrm{t} / \mathrm{ha}$ in the A1 resettlement to $28 \mathrm{t} / \mathrm{ha}$ in the large scale production system. In addition, yield variation within the production systems is very wide. For example, the largest yield range of 8 to $45 \mathrm{t} / \mathrm{ha}$ was reported in the communal area production indicating a tremendous opportunity to improve yield in this system. The initial step therefore, would be to narrow this actual yield gap. The concept of closing yield gaps to increase food production has recently come under extensive discussion (Mueller et al., 2012; Tittonell and Giller, 2013; Smith et al., 2013). Hence one strategy to reduce GHG emissions on a per-tonne-produce basis is to improve yield. Moreover, considering the wide range of emissions for each activity across the production systems, there is opportunity for growers in the upper end of the range to initially lower emissions toward the mean emissions and progressively toward the lower end. For example, considering emissions due to fertiliser production, the widest range is in the large scale and A2 resettlement production systems. This suggests that these two systems have the greatest prospect to lower emissions through increasing yields while even lowering fertiliser application rates. Probably lack of knowledge of the emission sources and the requisite mitigation strategies among the Zimbabwean potato growers is the challenge. Another dimension in the Zimbabwean case is the fact that the generous $\mathrm{N}$ applications are not matched by correspondingly high potato yields. This may imply the need for re-visiting fertiliser recommendations in potato production. Such studies should recommend application rates that match the availability of $\mathrm{N}$ in the soil with plant need or uptake to prevent over-application. Related to this fact could be the genetic yield potential of the old cultivars released in the 1980s that growers are currently using (Joyce, 1982). The potato breeding programme in Zimbabwe has been dysfunctional since the late 1990s to date, hence new cultivars with high yield potential, locally adapted and probably with high $\mathrm{N}$ uptake efficiency have not been made available to growers (Mazarire, personal communication, 2014). Reducing $\mathrm{N}$ application should be possible by growers currently over-applying 
$\mathrm{N}$ in order to reduce its impact on total GHG emissions (Lal, 2004). However, the synergy in this mitigation strategy is large gains in the efficiency of $\mathrm{N}$ uptake so as to maintain yields.

Sustainable/ecological intensification of potato production in Zimbabwe should take the route of improving nutrient use efficiency through practices that increase yield at the current or even lower rates of fertiliser use. Such intensified use of current potato lands will slow down the need for arable land expansion to increase potato production.

Extensive soil disturbance is another common cultural practice already alluded to in Zimbabwe potato production. No-till or reduced tillage practices could be encouraged in order to reduce the ridging operations from two or three to only one. Hillier et al. (2011) reported a reduction of soil GHG emission of $429 \mathrm{~kg} \mathrm{CO}_{2}$ eq./ha due to reduced or no-till farming. Operations contributing relatively small amounts to the total GHG emissions but with easily implementable measures could be targeted as well. To illustrate, pesticide application by tractor can be replaced by a 'spraying gang' of men with knapsack sprayers. One large-scale commercial grower encountered in the study sample introduced a spraying team of ten workers in 2007/8 during fuel shortages in Zimbabwe, and is still using this practice. Other growers tank-mix a number of biocides to minimise tractor trips in the field thereby reducing energy-related emissions.

Growers can employ the CFT-Potato model as an important first step to practically explore mitigation options. In this study, mitigation options were not assessed. Rather drawing from literature, possible mitigation activities were suggested for specific farm operations in the Zimbabwean case. The model output displays the factors or farm operations and their respective emissions and in this way it allows the user to choose the factors or farm operations to work on for reducing the carbon footprint. For example, the grower may decide to first target farm operations contributing the most to the total GHG emissions. In the Zimbabwean case, fertiliser production is the main contributor, followed by irrigation in the A2 resettlement and large-scale commercial production systems, then soil-related, pesticides and the rest of the operations.

\section{Benchmarking GHG emission performances of growers}

Although benchmarking was not assessed in this study, opportunities for it exist in the Zimbabwe potato case because of a large variation in amounts of GHG emission among the growers. The variation in GHG emission, is related to the variation in grower cultural practices such as nutrient and pesticide application rates, irrigation water use, mechanisation and potato yield both within and across production systems. Benchmarking should allow growers to compare their performance with that of fellow growers, especially within the production systems on several aspects of potato farming (De Snoo, 2006). During the data collection exercise in Zimbabwe, many potato farmer groups were encountered in the different areas and these institutional arrangements could be used as platforms or arena for operationalising benchmarking. Many growers interviewed had no idea of their own 
performance on GHG emissions. While they could respond easily to their cultural practices and input use rates in potato production, they had no idea how they compared to other potato growers in their local area or region. Moreover there is good farmer coordination by agricultural extension officials who frequently convene meetings to discuss farming-related issues. Hence there is a strong possibility to use benchmarking as a tool for growers to adopt more sustainable approaches in potato growing in Zimbabwe.

\section{Conclusions}

The CFT-Potato model allows for the estimation of the contribution of a range of farm operations to the total GHG emission of potato under different production systems with relative ease. It showed that there were large differences among production systems and among farmers within each production system in performance. The analysis helps growers to decide practical steps to explore mitigation options and benchmarking for continuous improvement. The study recommends potato growers in Zimbabwe to use this open source software to gain knowledge of GHG emission practices and especially the overriding importance of fertiliser usage in determining the carbon footprint of potato production and the need to account for it.

\section{Acknowledgement}

This research was conducted under the Wageningen University and Research Centre Sandwich PhD programme of the Netherlands (Grant number: 318330), with additional funding from the Chinhoyi University of Technology, Zimbabwe (Grant number: RB2240) for field data collection in Zimbabwe. The authors gratefully acknowledge the financial support from these two institutions. We express special thanks too, to stakeholders in the potato industry in Zimbabwe and the farmers that provided the data analysed in this manuscript.

\section{References}

Bellarby, J., Stirling, C., Vetter, S.H., Kassie, M., Kanampiu, F., Sonder, K., Smith, P., ～Hillier, J., 2014. Identifying secure and low carbon food production practices: a case study in Kenya and Ethiopia. Agric. Ecosyst. Environ. 197, 137 - 146.

Chikowo, R., Mapfumo, P., Nyamugafata, P., Giller, K.E., 2004. Mineral N dynamics, leaching and nitrous oxide losses under maize following two-year improved fallows on a sandy loam soil in Zimbabwe. Plant Soil. 259, 315-330.

Cool Farm Tool Institute, 2012. URL http://www.coolfarmtool.org/ [Accessed 10-06-2013].

De Snoo, G.R., 2006. Benchmarking the Environmental Performances of Farms. Int. J. LCA. $11(1), 22-26$.

Dlamini, A.M., Dube, M.A., 2014. Contribution of Animal Agriculture to Greenhouse Gases Production in Swaziland. American Journal of Climate Change. 3, 253-260. 
Food and Agriculture Organization of the United Nations (FAO), 2006. Fertilizer use by crop in Zimbabwe, Land and Plant Nutrition Management Service, Land and Water Development Division. Rome. http://www.fao.org/docrep/009/a0395e/a0395e00.HTM [Accessed 21-112014].

Gomez, K.A., Gomez, A.A., 1984. Statistical procedures for agricultural research, second ed., Wiley, New York.

Haverkort, A.J., Hillier, J.G., 2011. Cool Farm Tool-Potato: Model Description and Performance of Four Production Systems. Potato Res. 54, 355-369. DOI 10.1007/s11540-011-9194-1.

Haverkort, A.J., Sandana, P., Kalazich, J., 2014. Yield Gaps and Ecological Footprints of Potato Production Systems in Chile. Potato Res. 57(1), 13-31.

Hickman, J.E., Havlikova, M., Kroeze, C., Palm, C.A., 2011. Current and future nitrous oxide emissions from African agriculture. Curr. Opin. Environ. Sustain. 3, 370-378.

Hillier, J.G., Hawes, C., Squire, G., Hilton, A., Wale, S., Smith, P., 2009. The carbon footprints of food crop production. Int. J. Agric. Sust. 7, 107-118.

Hillier, J., Walter, C., Malin, D., Garcia-Suarez, T., Mila-i-Canals, L., Smith, P., 2011. A farmfocused calculator for emissions from crop and livestock production. Environ. Model Software 26, 1070-1078.

IPCC, 2006. Guidelines for National Greenhouse Gas Inventories of the International Panel on Climate Change, in: Eggleton, H.S., Buendia, L., Miwa, K., Ngara, T., Tanabe, K., (Eds.), The National Greenhouse Gas Inventories Programme, Institute for Global Environmental Strategies, Tokyo, Japan.

Joyce, M.J., 1982. Some Aspects of Seed Potato Production in Zimbabwe, International Potato Course: Production, Storage, and Seed Technology, Report of Participants, International Agricultural Centre, Wageningen, The Netherlands.

Lal, R., 2004. Agricultural activities and the global carbon cycle. Nutrient Cycling in Agroecosystems 70, 103-116.

Manzira, C., 2011. Potato production handbook, Potato Seed Association, Harare, Zimbabwe.

Mapanda, F., Wuta, M., Nyamangara, J., Rees, R.M., 2011. Effects of organic and mineral fertilizer nitrogen on greenhouse gas emissions and plant-captured carbon under maize cropping in Zimbabwe. Plant Soil 343, 67-81.

Mueller, N.D., Gerber, J.S., Johnston, M., Ray, D.K., Ramankutty, N., Foley, J.A., 2012. Closing yield gaps through nutrient and water management. Nature 490, 254-257. 
Palm, C.A., Smukler, S.M., Sullivan, C.C., Mutuo, P.K., Nyadzi, G.I., Walsh, M.G., 2010. Identifying potential synergies and trade-offs for meeting food security and climate change objectives in sub-Saharan Africa. PNAS 107, pp. 19661-19666.

Quiroz, R., Harahagazwe, D., Condori, B., Barreda, C., de Mendiburu, F., Amele, A., Antony, D., Atieno, E., Bararyenya, A., Byarugaba, A., Demo, P., Guerrero, J., Kowalski, B., Kude,D.A., Lungáho, C., Mares, V., Mbiri, D., Mulugeta, G., Nasona, B., Ngugi, A., Njeru, J., Ochieng, B., Onditi, J., Parker, M., Randrianaivoarivony, J.M., Schulte-Geldermann, E., Tankou, C.M., Woldegiorgis, G., Worku, A., 2014. Potato yield gap analysis in SSA through participatory modeling: Opimizing the value of historical breeding trial data, CIP Working Paper, Lima, Peru, 27 pp.

Reay, D.S., Davidson, E.A., Smith, K.A., Smith, P., Melillo, J.M., Dentener, F., Crutzen, P.J., 2012. Global agriculture and nitrous oxide emissions. Nat. Clim. Change 2, 410- 416.

Rees, R.M., Wuta, M., Furley, P.A., Li, C.S., 2006. Nitrous oxide fluxes from savanna (miombo) woodlands in Zimbabwe. J. Biogeogr. 33, 424-43.

Saggar, S., Luo, J., Kim, D.G., Jha, N., 2011. Intensification in pastoral farming: impacts on soil attributes and gaseous emissions, in: Singh, B.P., Cowi, A., Chan, Y., (Eds.), Soil Health and Climate Change (Soil Biology Series), Springer-Verlag, pp. 207-236.

Smith, P., Martino, D., Gwary, D., Janzen, H., Kumar, P., McCarl, B., Ogle, S., O’Mara, F., Rice, C., Scholes, B., Sirotenko, O., Howden, M., McAllister, T., Romanenkov, V., Schneider, U., Towprayoon, S., Wattenbach, M., Smith, J., 2008. Greenhouse gas mitigation in agriculture. Philos. Trans. R. Soc. B. Biol. Sci. 363, 789-813.

Smith, P., Haberl, H., Popp, A., Erb, K., Lauk, C., Harper, R., Tubiello, F.N., de SiqueiraPinto, A., Jafari, M., Sohi, S., Masera, O., Böttcher, H., Berndes, G., Bustamante, M., Ahammad, H., Clark, H., Dong, H., Elsiddig, E.A., Mbow, C., Ravindranath, N.H., Rice, C.W., Robledo-Abad, $\quad$ C., Romanovskaya, A., Sperling, F., Herrero, M., House, J.I., Rose, S., 2013. How much land-based greenhouse gas mitigation can be achieved without compromising food security and environmental goals? Global Change Biol. 19, 2285-2302.

Struik, P.C., Kuyper, T.W., 2014. Editorial overview: Sustainable intensification to feed the world: concepts, technologies and trade-offs. Curr. Op. in Environ. Sust. 8, vi-vii http://dx.doi.org/10.1016/j.cosust.2014.10.008, [Accessed 07-11-2014].

Svubure, O., Struik, P.C., Haverkort, A.J., Styen, J.M., 2015. Yield gap analysis and resource footprints of Irish potato production systems in Zimbabwe, Field Crop Res.178:77-90, DOI: 10.1016/j.fcr.2015.04.002. 
The Herald, 2012. Potato declared strategic security food crop, The Herald, $18^{\text {th }}$ May, 2012 http://www.herald.co.zw/potato-declared-strategic-food-security-crop/, [Accessed 23-07-13].

Tittonell, P., Giller, K.E., 2012. When yield gaps are poverty traps: the paradigm of ecological intensification in African smallholder agriculture. Field Crops Res. 143, 76-90.

VSN International, 2011. GenStat for Windows $16^{\text {th }}$ Edition. VSN International, Hemel Hempstead, United Kingdom, http://www.vsni.co.uk/webstore/software/genstat/, [Accessed 07-10-2014]. 